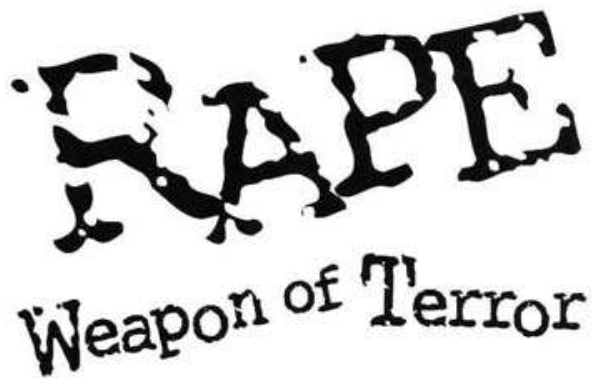


This page is intentionally left blank 


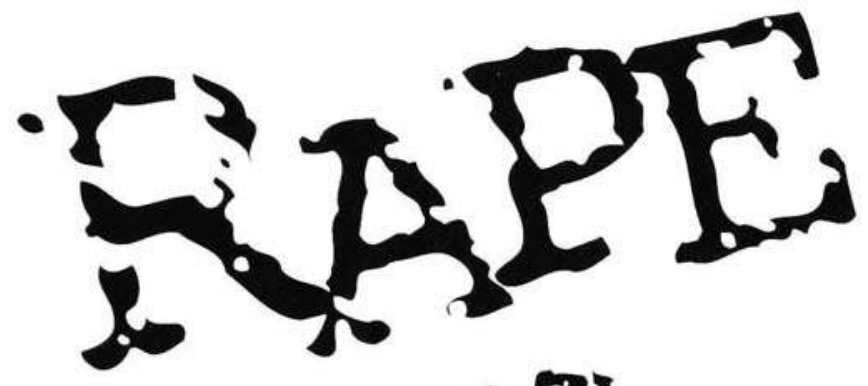

Weapon of Terror

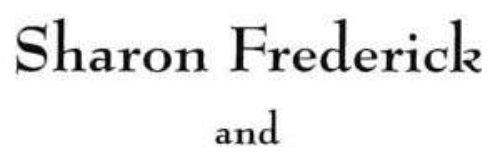

The Aware Committee on Rape

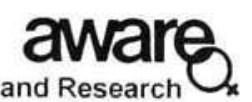


Published by

Global Publishing Co. Inc.

1060 Main Street, River Edge

NJ 07661, USA

\section{RAPE: WEAPON OF TERROR}

Copyright $\odot 2001$ by Global Publishing Co. Inc.

All rights reserved. This book, or parts thereof, maynot be reproduced in any form or by any means, electronic or mechanical, including photocopying, recording or any information storage and retrieval system now known or to be invented, without written permission from the Publisher.

For photocopying of material in this volume, please pay a copying fee through the Copyright Clearance Center, Inc., 222 Rosewood Drive, Danvers, MA 01923, USA. In this case permission to photocopy is not required from the publisher.

ISBN $\quad 1-879771-53-5$

Printed in Singapore by World Scientific Printers 
This book is dedicated to all victims of rape past. present and future. It is also dedicated to the memory of Dorothy Cheung. who helped inspire the writing of this book as a founding member of the AWARE committee on rape. 
This page is intentionally left blank 


\section{FOREWORD}

The human, social and economic cost of gender-based violence is incalculable. Transcending boundaries of nationality, culture, religion and socioeconomic status, violence against women and girls in its different manifestations plagues every society through harmful consequences to women's physical and emotional health, loss of self-esteem, and as a leading cause of death of women through murder and suicide. Affecting the capacity of over half the world's population to freely and fully participate in the development process, violence against women and girls carries exorbitant social and economic costs that have yet to be fully and accurately assessed.

The issue of violence against women has brought some of the century's greatest challenges, but also some of the most powerful victories for human rights that have served to place violence against women onto the international agenda as a human rights and a development concern of the highest priority. The United Nations Development Fund for Women (UNIFEM) supports innovative initiatives worldwide to combat all forms of violence against women, including domestic violence, sexual violence and harassment in the school and in the workplace, rape and sexual slavery in the context of war, trafficking in women across borders, as well as violence associated with traditional practices.

I commend the Association of Women for Action and Research (AWARE) for their initiative to publish the book Rape: Weapon of Terror. This book promises to serve as a tool for advancing the goal 
of eliminating violence against women, especially in the context of situations of war and civil conflict. The use of gender-based violence, including rape and forced pregnancy, is increasingly a horrifying feature of war in ethnic conflicts. As more and more women and girls are abducted by warring groups, displaced from their homes and communities, and threatened with deadly diseases such as HIVIAIDS, they are at the same time called upon to assume wider responsibility for holding their communities together, taking new leadership roles and often sustaining their families singlehandedly. All of these experiences have brought home to many women the vivid links between violence, poverty and inequality. They see clearly the continuum of conflict that stretches from the beating at home to the rape on the street to the killing on the battlefield.

This new book serves to broaden our knowledge and understanding of gender-based violence as a weapon of war. At the same time it also highlights the need for effective intervention in the area of peace building and conflict resolution. There is a need to find common ground between civil societies and states, the United Nations system and business communities so as to rebuild institutions and capacities, and to bring international agreements and treaties to bear upon the operation of economic and political systems.

Noeleen Heyzer Executive Director, UNIFEM 


\section{CONTENTS}

Foreword vii

Introduction 1

Civilian targets of war 4

Rape in the eyes of the law 6

Lessons from the Past $\quad 10$

Women as property, banner and booty 12

Foundations for today: Rape as a crime against honour 13

World War I: Rape as a tool of terror and propaganda 14

World War II in Europe: Establishing a master race 16

World War II in Asia: Widespread sexual atrocities 18

Violence on Three Continents 25

Haiti: No punishment, no progress 25

Civilians fair game for military 27

Bosnia: Broadcasting atrocities $\quad 30$

"Ram" Plan: Assault the most vulnerable 33

Brutality, humiliation, torture 36

Rwanda: 100 days of atrocities $\quad 38$

$\begin{array}{ll}\text { As many killers as victims } & 40\end{array}$

Alive but dying 41

Assaults in Asia 46

Afghanistan: Resistance groups versus civilians 48 
Rape to intimidate, punish and reward 50

Sex slaves and prostitutes 52

Myanmar: Repressive military regime 53

Minorities as enemies $\quad 55$

Kashmir: Claimed by two nations $\quad 58$

$\begin{array}{ll}\text { Brutality on all sides } & 60\end{array}$

Rape to humiliate the community 62

Indonesia: A History of Control and Corruption 66

Aceh: Fiercely independent 69

East Timor: Decades of military control 73

Irian Jaya: Often overlooked troublespot $\quad 78$

Jakarta: Targeting ethnic Chinese 80

Where We Are, What We Can Do 86

$\begin{array}{ll}\text { Why sexual assault? } & 87\end{array}$

The horrible consequences of rape 89

Violence begets action - finally 91

Sometimes yes, sometimes no 93

Where to go from here? 96

5 things that you can do now 97

5 things that your country should do.... and you should lobby for $\quad 98$

5 things that the international community should do 98

$\begin{array}{ll}\text { Appendix } & 101\end{array}$

Epilogue: The AWARE Committee on Rape 117 


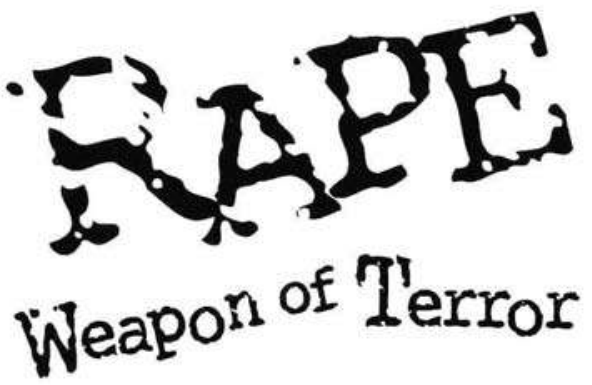

